\title{
Restrukturisasi Badan Usaha Milik Negara Perbankan Melalui Pembentukan Holding Company Di Indonesia
}

\author{
Agus Prasetiyo \\ Program Pascasarjana Ilmu Hukum Univesitas Islam Indonesia \\ Jln. Cik Di Tiro No. 1, Yogyakarta, 55223 \\ agus_pieng@yahoo.co.id
}

\begin{abstract}
The purpose of the study is to analyze the aspects, strengths and weaknesses in restructuring StateOwned Banks (BUMN Banks) through the establishment of a holding company in Indonesia. This is a normative legal research with the regulatory approach. The method used in the data collection is by collecting the legals materials and the study of documents. The analysis of legal materials uses the descriptive-qualitative (juridical-normative) approach. Conclusion of the results of the study: First, aspects that need to be considered in the establishment of a BUMN holding company include legal (juridical) and non-legal aspects such as economics and so on. Second, there are more advantages compared to weaknesses in the establishment of a BUMN holding company. This effort is an alternative choice or step to form a strong financial and banking institution in the ASEAN region
\end{abstract}

Keywords: ASEAN; holding company; state-owned banks

\begin{abstract}
Abstrak
Tujuan penelitian untuk menganalisis aspek-aspek, kelebihan dan kelemahan dalam restrukturisasi Badan Usaha Milik Negara (BUMN) Perbankan melalui pembentukan holding company di Indonesia. Jenis penelitian hukum normatif dengan pendekatan peraturan perundang-undangan. Metode pengumpulan bahan hukum dengan studi dokumen. Analisis bahan hukum menggunakan analisis deskriptif kualitatif (yuridis-normatif). Kesimpulan hasil penelitian: Pertama, aspek-aspek yang perlu diperhatikan dalam pembentukan holding company BUMN Perbankan meliputi aspek hukum (yuridis) dan nonyuridis seperti ekonomi dan sebagainya. Kedua, lebih banyak kelebihan dibandingkan dengan kelemahan pada pembentukan holding company BUMN Perbankan. Upaya tersebut merupakan salah satu pilihan atau langkah alternatif untuk membentuk lembaga keuangan dan perbankan yang kuat di kawasan ASEAN.
\end{abstract}

Kata-kata Kunci: ASEAN; BUMN perbankan; holding company 


\section{Pendahuluan}

Pelaku utama (pilar) ekonomi nasional meliputi BUMN, swasta, dan koperasi. Kerjasama antar pilar ekonomi harus dikembangkan bukan hanya atas dasar saling menguntungkan, melainkan juga atas dasar peranan masing-masing sebagai mitra usaha, tanpa melupakan asas dan sendi dasar masing-masing badan usaha. ${ }^{1}$ Intervensi negara dalam kegiatan ekonomi diperlukan untuk mengurangi kegagalan pasar, kekakuan harga, dan dampak eksternalitas pada lingkungan alam dan sosial. ${ }^{2}$ Negara hadir dalam dalam kegiatan ekonomi melalui regulasi hukum atau kebijakan yang mengatur kegiatan ekonomi dan badan usaha (BUMN) sebagai pelaku usaha.

Badan Usaha Milik Negara (BUMN) adalah badan usaha yang seluruh atau sebagian besar modalnya dimiliki oleh negara melalui penyertaan secara langsung yang berasal dari kekayaan negara yang dipisahkan. ${ }^{3}$ BUMN memiliki keistimewaan karakteristik yang tidak dimiliki badan usaha lain adalah suatu badan usaha "berbaju pemerintah" tetapi mempunyai fleksibilitas dan inisiatif seperti perusahaan swasta. ${ }^{4}$ Perbedaan BUMN dapat dilihat dari segi jenis (sektor) usahanya.

Perbankan sebagai lembaga keuangan mempunyai nilai strategis dalam perekonomian suatu negara. ${ }^{5}$ Perbankan adalah segala sesuatu yang menyangkut tentang bank, mencakup kelembagaan, kegiatan usaha, serta cara dan proses dalam melaksanakan kegiatan usahanya. $^{6}$ Jenis bank berdasarkan kepemilikannya terdiri dari: a) bank pemerintah; b) bank swasta nasional; c) bank milik koperasi; d) bank milik asing; e) bank campuran. ${ }^{7}$ Statistik Perbankan Indonesia (SPI) periode November 2018 menunjukkan bahwa bank umum di Indonesia berjumlah 115 bank. ${ }^{8}$ Jumlah tersebut dinilai terlalu banyak, maka

${ }^{1}$ Pandji Anoraga, BUMN, Swasta, dan Koperasi: Tiga Pelaku Ekonomi, Pustaka Jaya, Jakarta, 1995, hlm. 169170.

${ }^{2}$ Ibid., hlm. 10 .

${ }^{3}$ Undang-Undang Nomor 19 Tahun 2003 tentang Badan Usaha Milik Negara, Pasal 1 angka 1.

${ }^{4}$ Pandji Anoraga, Op.Cit., hlm. 2.

5 Trisadini P. Usanti dan Abd. Somad, Hukum Perbankan Edisi Pertama, Kencana, Depok, 2017, hlm. 1.

${ }^{6}$ Undang-Undang Nomor 10 Tahun 1998 tentang Perubahan Undang-Undang Nomor 7 Tahun 1992 tentang Perbankan, Pasal 1 angka 1

${ }^{7}$ Dadang Husen Sobana, Hukum Perbankan di Indonesia, Pustaka Setia, Bandung, 2016, hlm. 52.

8"Perbanas Jumlah Bank Harus Dikurangi", https://finance.detik.com/moneter/d-4404232/perbanasjumlah-bank-harus-dikurangi, diakses tanggal 6 Februari 2019. 
dibutuhkan konsolidasi agar jumlah bank bisa lebih padat untuk efisensi usaha dan peningkatan aset perbankan.

Bank milik pemerintah meliputi Bank Mandiri, BRI, BNI, dan BTN. Menurut Majalah Forbes tahun 2018, tidak ada BUMN Perbankan yang masuk daftar 5 (lima) bank dengan jumlah aset dan kapitalisasi pasar terbesar di kawasan ASEAN. ${ }^{9}$ BUMN Perbankan dapat melakukan restrukturisasi melalui pembentukan holding company untuk membentuk lembaga keuangan yang kuat di kawasan ASEAN. Berdasarkan hukum di Indonesia baik hukum BUMN, perusahaan, perbankan, dan persaingan usaha tidak diatur secara tegas mengenai pembentukan holding company. Perusahaan induk atau holding company adalah suatu perusahaan yang bertujuan memiliki saham dalam satu atu lebih perusahaan lain dan/atau mengatur salah satu atau lebih perusahaan lain tersebut. 10

Perilaku dan kegiatan perusahaan sangat besar dipengaruhi oleh ekonomi lokal maupun nasional, bahkan internasional. ${ }^{11}$ Restrukturisasi BUMN Perbankan melalui pembentukan holding company bertujuan meningkatkan persaingan di pasar global khususnya kawasan ASEAN. Pada kawasan regional, dengan dibentuknya MEA (Masyarakat Ekonomi ASEAN) pada 2015 untuk industri sektor riil pada 2020 untuk industri keuangan dan perbankan, maka persaingan bisnis di wilayah ekonomi ASEAN semakin meningkat.

Perusahaan-perusahaan di kawasan ASEAN yang tidak memiliki daya saing tinggi dapat dipastikan akan mengalami kesulitan apabila tidak mampu beradaptasi dengan kondisi pasar yang ada. ${ }^{12}$ Kawasan ASEAN merupakan salah satu pasar potensial bagi pelaku usaha lokal, regional, maupun global. MEA dibentuk untuk mendorong kemajuan pengelolaan ekonomi di negara

"List of Largest Banks in Southeast Asia", https://en.wikipedia.org/wiki/List_of_largest_banks_in_ Southeast_Asia, diakses tanggal6 Februari 2019.

${ }^{10}$ Munir Fuady, Hukum Perusahaan Dalam Paradigma Hukum Bisnis: Berdasarkan Undang-Undang Nomor 40 Tabun 2007, Citra Aditya Bakti, Bandung, 2009, hlm. 85-86.

${ }^{11}$ Sri Redjeki Hartono, Kapita Selekta Hukum Perusahaan, Mandar Maju, Bandung, 2000, hlm.11.

12 Subarjono Joyosumarto, B.A.N.K.I.R: Kepemimpinan Lembaga Perbankan Abad Ke-21, Elex Media Komputindo, Jakarta, 2018, hlm. 5. 
anggotanya, meningkatkan daya saing, dan memperbaiki taraf hidup masyarakat. ${ }^{13}$

Dunia bisnis sudah semakin berubah, dimana teknologi sebagai primary agent of change telah mengubah berbagai lini kehidupan manusia modern. ${ }^{14}$ Dunia mengalami perubahan, BUMN harus melihat ancaman dan peluang dari eksternal agar tidak punah. Pembentukan holding jasa keuangan molor tiga tahun dari target.

Pemerintah menargetkan aturan terkait holding keuangan bank BUMN pada September 2016. ${ }^{15}$ Namunhingga saat ini belum ada perkembangan yang berarti pembentukan holding BUMN Perbankan. Pemerintah harus memperhatikan berbagai aspek agar upaya tersebut tidak mengalami kegagalan.

\section{Rumusan Masalah}

Adapun rumusan permasalahan yang dipaparkan dalam karya tulis ini adalah sebagai berikut: Pertama, apa sajakah aspek yang perlu diperhatikan dalam restrukturisasi BUMN Perbankan melalui pembentukan holding company di Indonesia? Kedua, bagaimana kelebihan dan kelemahan restrukturisasi BUMN Perbankan melalui pembentukan holding company di Indonesia?

\section{Tujuan Penelitian}

Berdasarkan rumusan permasalahan tersebut di atas, adapun tujuan dari penelitian ini adalah sebagai berikut: Pertama, menganalisis aspek-aspek dalam restrukturisasi BUMN Perbankan melalui pembentukan holding company di Indonesia. Kedua, menganalisis kelebihan dan kelemahan restrukturisasi BUMN Perbankan melalui pembentukan holding company di Indonesia.

\section{Metode Penelitian}

Penelitian ini termasuk penelitian hukum normatif (doktrinal), di mana mengkaji hukum dalam konsep hukum sebagai norma atau aturan. ${ }^{16}$ Penelitian

${ }^{13}$ Ibid, hlm. 37.

14 Ahmad Bambang, Marketing Platform for BUMN: d'Gil Marketing 2, Gramedia Pustaka Utama, Jakarta, 2017, hlm. 9-10.

15"Holding Jasa Keuangan”, http://amp.kontan.co.id/news/holding-jasa-keuangan-bank-bumn-molortiga-tahun-dari-target, diakses tanggal6 Februari 2019.

${ }^{16}$ Soetandyo Wignjosoebroto, Hukum: Konsep dan Metode, Setara Press, Malang, 2013, hlm. 12. 
hukum doktrinal berdasarkan konsep dan dikembangkan atas doktrinpengkonsep/pengembangnya. ${ }^{17}$ Penelitian ini menggunakan pendekatan peraturan perundang-undangan yang bersifat comprehensive, all-inclusive, dan systematic. ${ }^{18}$ Metode pengumpulan bahan hukum dengan studi pustaka (dokumen). Analisis bahan hukum dengan analisis deskriptif kualitatitif (yuridis normatif) melalui tahapan pengumpulan data, reduksi data, sajian data, dan penarikan kesimpulan.

\section{Hasil Penelitian dan Pembahasan}

\section{Aspek-aspek dalam Restrukturisasi BUMN Perbankan melalui Pembentukan Holding Company di Indonesia}

Restrukturisasi adalah upaya yang dilakukan dalam rangka penyehatan BUMN yang merupakan salah satu langkah strategis untuk memperbaiki kondisi internal perusahaan guna memperbaiki kinerja dan meningkatkan nilai perusahaan. ${ }^{19}$ Restrukturisasi merupakan tindakan atau kegiatan untuk mengubah struktur perusahaan dengan tujuan memperbaiki dan memaksimalkan. ${ }^{20}$ Sebuah perusahaan perlu memikirkan suatu restrukturisasi perusahaan, apabila menginginkan usahanya dapat melakukan persaingan usaha dengan perusahaan-perusahaan lainnya baik di tingkat nasional maupun internasional.

Restrukturisasi usaha adalah melakukan penataan terhadap nilai seluruh rantai bisnis perusahaan dengan tujuan terciptanya daya saing dan kompetisi, serta cara yang dapat dilakukan untuk mendapat restrukturisasi adalah melalui: merger dan akuisisi; regrouping holding and consolidation; joint operation and management; strategic alliance; discontinue some business or product or branch: break up the firm to some companies; likuidasi. ${ }^{21}$

\footnotetext{
${ }^{17}$ M. Syamsudin, Operasional Penelitian Hukum, RajaGrafindo Persada, Jakarta, 2007, hlm. 21.

18 Johnny Ibrahim, Teori dan Metode Penelitian Hukum Normatif, Bayumedia Publishing, Malang, 2005, hlm. 302-303.

${ }^{19}$ Undang-Undang Nomor 19 Tahun 2003 tentang Badan Usaha Milik Negara, Pasal 1 angka 11.

20 Zaeni Asyhadie dan Budi Sutrisno, Hukum Perusahaan dan Kepailitan, Erlangga, Jakarta, 2012, hlm. 173.

${ }^{21}$ Ridwan Khairandy, Perseroan Terbatas: Doktrin, Paraturan Perundang-undangan, dan Yurisprudensi, Kreasi Total Media, Yogyakarta, 2009, hlm. 280.
} 
Salah satu langkah yang di ambil pemerintah dalam rangka restrukturisasi BUMN Perbankan dengan melakukan pembentukan holding company. Salah satu sektor yang mendapat perhatian kebijakan tersebut adalah sektor perbankan dan keuangan. Tujuan restrukturisasi untuk: a) meningkatkan kinerja dan nilai perusahaan; b) memberikan manfaat berupa dividen dan pajak kepada negara; c) menghasilkan produk dan layanan dengan harga yang kompetitif kepada konsumen; d) memudahkan pelaksanaan privatisasi. ${ }^{22}$ Pada dasarnya alasan dan latar belakang melakukan restrukturisasi perusahaan adalah alasan dan pemikiran yang bersifat ekonomis dan manajerial. ${ }^{23}$

Faktor penyebab terjadinya restrukturisasi BUMN secara makro antara lain: masalah hukum atau desentralisasi; masalah hukum atau monopoli; tuntutan pasar; masalah geografis; perubahan kondisi geografis; hubungan holding-anak perusahaan; masalah serikat pekerja; perubahan image korporasi; fleksibilitas manajemen; pergeseran kepemilikan; akses modal yang lebih baik. ${ }^{24}$ Berdasarkan aspek lain yang bersifat non yuridis adalah cara restrukturiasi yang dipilih. Perbedaan holding company dengan opsi lainnya merujuk pada beberapa faktor yang harus dipertimbangkan. Hukum berperan sebagai pengaman dan pedoman untuk kegiatan restrukturisasi perusahaan.

Pembentukan holding company dalam peraturan-perundang-undangan di Indonesia tidak diatur secara tegas. Strategi pembentukan holding company dipilih karena masih mempertahankan keberadaan bank-bank BUMN. Konsekuensi dari restrukturisasi suatu badan usaha adalah perubahan perlakuan dalam beberapa aspek internal perusahaan. Menurut Toto Pranoto dan Willem A. Makaliwe, aspek-aspek yang perlu diperhatikan dalam pembentukan holding company di Indonesia ${ }^{25}$ antara lain: a. Aspek hukum berhubungan dengan pembentukan badan hukum baru atau penunjukan perusahaan yang telah ada sebagai relasi kendali simetris yang membawahi kedua BUMN dengan memperhatikan eksistensi kedua BUMN Perbankan atau lebih. Saham pemerintah di BUMN

${ }^{22}$ Undang-Undang Nomor 19 Tahun 2003 tentang Badan Usaha Milik Negara, Pasal $72 .$.

${ }^{23}$ Sri Redjeki Hartono, Op. Cit., hlm. 39.

${ }^{24}$ Gatot Supramono, BUMN Ditinjau Dari Segi Hukum Perdata, Rineka Cipta, Jakarta, 2016, hlm. 166-170.

25"Restrukturisasi Holding Company", http://www.lmfeui.com/data/Restrukturisasi_Holding _Company\%20Revisi\%202.pdf, diakses tanggal6 Februari 2019. 
Perbankan yang dijadikan anak usaha holding berpindah atau dialihkan atau berpindah ke BUMN yang dijadikan holding company yaitu Indonesia Danarekasa; b. Aspek Sumber Daya Manusia (SDM) dan budaya perusahaan berhubungan dengan status kepegawaian di perusahaan induk bisa berbeda dengan anak perusahaan. Sistem SDM (termasuk remunerasi) di perusahaan induk bisa berbeda dengan anak perusahaan. Budaya perusahaan di perusahaan induk bisa berbeda dengan anak perusahaan; c. Aspek Perpajakan adalah tidak ada pajak terutang karena hanya terjadi pengalihan saham milik pemerintah ke BUMN yang ditunjuk sebagai holding yaitu Indonesia Danareksa. Meskipun terdapat capital gain atas pengalihan saham tersebut, namun karena pemerintah bukan merupakan subjek pajak maka tidak dikenakan Pajak Penghasilan (PPh).

Selain ketiga aspek tersebut, dasar hukum dan aspek lain yang perlu diperhatikan antara lain dalam pembentukan holding company antara lain: Pertama, UU Indonesia. 19 Tahun 2003 tentang Badan Usaha Milik Negara (UU BUMN). Pasal 73 UU BUMN mengatur bahwa restrukturisasi meliputi: a. Restrukturisasi sektoral yang pelaksanaannya disesuaikan dengan kebijakan sektor dan/atau ketentuan peraturan perundang-undangan; b. Restrukturisasi perusahaan/korporasi yang meliputi: 1) peningkatan intensitas persaingan usaha, terutama di sektor-sektor yang terdapat monopoli, baik yang diregulasi maupun monopoli alamiah; 2) penataan hubungan fungsional antara pemerintah selaku regulator dan BUMN selaku badan usaha, termasuk di dalamnya penerapan prinsip-prinsip tata kelola perusahaan yang baik dan menetapkan arah dalam rangka pelaksanaan kewajiban pelayanan publik. 3) restrukturisasi internal yang mencakup keuangan, organisasi/ manajemen, operasional, sistem, dan prosedur.

Kedua, UU Indonesia. 40 Tahun 2007 tentang Perseroan Terbatas (UUPT). Pasal 126 ayat (1) UUPT mengatur bahwa perbuatan hukum penggabungan, peleburan, pengambilalihan, atau pemisahan wajib memperhatikan kepentingan: a. Perseroan, pemegang saham minoritas, karyawan Perseroan; b. Kreditor dan mitra usaha lainnya dari Perseroan; dan c. Masyarakat dan persaingan sehat dalam melakukan usaha. (2) Pemegang saham yang tidak setuju terhadap keputusan RUPS mengenai Penggabungan, Peleburan, Pengambilalihan, atau 
Pemisahan sebagaimana dimaksud pada ayat (1) hanya boleh menggunakan haknya sebagaimana dimaksud dalam Pasal 62. (3) Pelaksanaan hak sebagaimana dimaksud pada ayat (2) tidak menghentikan proses pelaksanaan penggabungan, peleburan, pengambilalihan, atau pemisahan.

Ketiga, UU Indonesia. 10 Tahun 1998 jo. UU Indonesia. 7 Tahun 1992 tentang Perbankan (UU Perbankan). Pasal 28 (1) UU Perbankan mengatur bahwa Merger, konsolidasi, dan akuisisi wajib terlebih dahulu mendapat izin Pimpinan Bank Indonesia. Aspek terkait dunia perbankan dalam sistem ekonomi melibatkan aspek langsung maupun tidak langsung seperti: a) masyarakat antar bank, nasabah, dan pemerintah yang merupakan aspek luar organisasi; b) bankir dan karyawan bank, serta pemilik merupakan aspek dalam organisasi. ${ }^{26}$

Keempat, UU Indonesia. 5 tahun 1999 tentang Larangan Praktik Monopoli dan Persaingan Usaha Tidak Sehat (UU Anti Monopoli). Pasal 12 UU Anti Monopoli mengatur tentang trust. Pembentukan holding company memungkinkan terjadi pemusatan konsentrasi horizontal yang dapat menimbulkan trust karena dengan bergabungnya perusahaan sejenis yang akhirnya dapat mengontrol produksi dan atau pemasaran atas barang dan atau jasa karena prinsip operating pada holding company mengakibatkan perusahaan induk terlibat langsung pada kegiatan operasional anak perusahaan. Holding company BUMN di Indonesia saat masih menjalankan sistem operating holding. Seharusnya bentuk pengelolaan holding company BUMN yang baik adalah Investment Holding. Holding BUMN memang sifatnya Monopoly by Law, yaitu monopoli oleh negara untuk cabangcabang produksi yang sangat vital bagi orang banyak. Menurut Saidah Sakwan anggota KPPU menyatakan holding BUMN diberikan konsesi oleh pemerintah untuk memonopoli dan tidak terikat pada hukum persaingan usaha. Holding BUMN memang sifatnya Monopoly by Law, yaitu monopoli oleh negara untuk cabang-cabang produksi yang sangat vital bagi orang banyak. Monopoli by Law didukung oleh regulasi, baik dalam bentuk undang-undang, Peraturan Pemerintah (PP), Peraturan Presiden (Perpres) maupun Peraturan Menteri (Permen). Dengan adanya keistimewaan yang didapatkan oleh sejumlah

${ }^{26}$ Rimsky K. Judisseno, Sistem Moneter dan Perbankan di Indonesia, Gramedia Pustaka Utama, Jakarta, 2005, hlm. 102-103. 
perusahaan negara, maka akan terbebas dari UU Anti Monopoli. Namun apabila holding BUMN tidak diregulasi dan hanya menjadi kebijakan korporasi atau komisaris perusahaan, maka KPPU bisa menindaknya sesuai dengan aturan yang berlaku. ${ }^{27}$

Kelima, Aspek Ekonomi. Menurut John D. Martin et.al., bentuk usaha Regrouping Holding and Consolidation adalah melakukan proses pengelompokan unit-unit, untuk ditempatkan dalam satu kendali sehingga memudahkan untuk dilakukan efisiensi, efektivitas, dan produktivitas sehingga terjadinya daya saing tinggi. ${ }^{28}$ Langkah holding-isasi terhadap BUMN Perbankan dalam rangka meningkatkan kinerja dan nilai perusahaan serta menciptakan efisien, efektif atau produktif, berdaya saing tinggi, dan mampu menjadi pelaku utama (champion) dalam industrinya baik nasional, regional dan bahkan global, perlu dilakukan rightsizing BUMN. ${ }^{29}$ Secara politik ekonomi, pendirian BUMN di Indonesia memiliki 3 alasan pokok, yaitu: Pertama, sebagai wadah bisnis dari aset asing yang telah nasionalisasi pada era 1950-an; Kedua, membangun industri yang diperlukan masyarakat, namun masyarakat (swasta) tidak mampu memasukinya karena alasan investasi atau risiko usaha yang sangat besar; Ketiga, membangun industri yang sangat strategis, berkenaan dengan keamanan negara. Dewasa ini, the only effective economic player in town adalah BUMN yang harapan untuk membawa perekonomian nasional lepas dari krisis 1997.30

Upaya holding-isasi yang dilakukan oleh pemerintah terhadap BUMN Perbankan di Indonesia diharapkan sebagai suatu langkah alternatif mewujudkan dan membentuk lembaga keuangan yang kuat memiliki daya saing global, khususnya untuk bersaing dalam sektor perbankan dan keuangan di kawasan ASEAN. Pemerintah harus memperhatikan berbagai aspek tersebut agar upaya holding company tidak mengalami kegagalan. Pembentukan holding company BUMN

27“KPPU Holding BUMN Diberikan Konsesi Memonopoli”, https://www.hukumonline.com/berita/ baca/lt57e536c431443/kppu--holding-bumn-diberikankonsesi-memonopoli, diakses tanggal 6 Februari 2019.

${ }^{28}$ Ridwan Khairandy, Op. Cit., hlm. 282.

29"Penguatan BUMN", pascasarjana.uai.ac.id/wp-content/uploads/2017/07/6.-PENGUATAN-BUMNedited1.pdf, diakses tanggal 6 Februari 2019. hlm. 4 .

30 Sugiharto, et.al., BUMN Indonesia: Isu, Kebijakan, dan Strategi, Elex Media Komputindo, Jakarta, 2005, 
Perbankan setidaknya akan ada kelompok usaha perbankan asal Indonesia dalam 5 besar bank dengan aset terbesar dan menjadi bank dengan kapitalisasi pasar terbesar di ASEAN. Sehingga bank asal Indonesia untuk masuk dalam pasar perbankan di negara-negara ASEAN lebih mudah karena memiliki permodalan yang kuat.

\section{Kelebihan dan Kelemahan Restrukturisasi BUMN Perbankan melalui Pembentukan Holding Company di Indonesia}

Undang-Undang Dasar 1945 (UUD 1945) mengamanatkan bahwa pelaku ekonomi nasional terdiri atas tiga bentuk usaha, yaitu swasta, BUMN, dan Koperasi. ${ }^{31}$ Eksistensi BUMN dimulai dari nasionalisasi-nasionalisasi perusahaanperusahaan Belanda. ${ }^{32}$ Sektor perbankan di Indonesia terkena dampak parah akibat krisis ekonomi. Sehingga apabila tidak didahulukan untuk disehatkan, maka bank-bank BUMN tidak bisa berperan lagi sebagai jantung perekonomian yang memompakan dari ke sektor riil. Hal itu karena Bank BUMN memberi modal ke masyarakat untuk melakukan kegiatan usaha. Dua kunci permasalahan perbankan pada masa itu adalah non-performing loan (kredit macet) dan negative spread (memberikan kerugian besar kepada perbankan). ${ }^{33}$

Hukum perbankan adalah sebagai sekumpulan hukum yang mengatur kegiatan lembaga keuangan bank yang meliputi segala aspek, dilihat dari segi esensi dan eksistensinya, serta hubungannya dengan bidang kehidupan lainnya. ${ }^{34}$ Program restrukturisasi perbankan mencakup berbagai langkah strategis yang berintikan kebijakan untuk memperbaiki kondisi solvabilitas dan profibilitas bank, melangsungkan kehidupan bank yang berprospek baik (viable), dan mengaktifkan lagi fungsi bank sebagai lembaga intermediasi. ${ }^{35}$ Salah satu langkah alternatif yaitu melalui pembentukan holding company BUMN Perbankan.

Pasca rekapitulasi, Bank Indonesia (BI) mengeluarkan berbagai kebijakan dengan tujuan untuk memperkuat kondisi perbankan nasional. ${ }^{36}$ Pertumbuhan sektor riil hanya didapatkan apabila perbankan berperan menjadi stimulus dari

${ }^{31}$ Djokosantoso Moeljono, Reinvensi BUMN: Empat Strategi Membangun BUMN Kelas Dunia, Elex Media Komputindo, Jakarta, 2004, hlm. 1.

${ }^{32}$ Ibid., hlm. 2.

33 Sugiharto, et.al., Op. Cit., hlm. 6.

34 Muhamad Djumhana, Hukum Perbankan di Indonesia, Citra Aditya Bakti, Bandung, 2012, hlm. 1.

35 Agus Budianto, Merger Bank di Indonesia, Ghalia Indonesia, Jakarta, 2004, hlm. 61.

36 Djoko Retnadi, Memilih Bank Yang Sehat: Kenali Kinerja dan Pelayanannya, Elex Media Komputindo, Jakarta, 2006, hlm. 41. 
sisi pembiayaan. ${ }^{37}$ BI mempunyai kedudukan yang sangat strategis dalam menciptakan iklim yang kondusif bagi kegiatan ekonomi dan menciptakan perbankan yang sehat, kuat, dan efisien. 38

Setiap bidang usaha pasti memiliki risiko termasuk sektor perbankan melipuri: risiko-risiko bank; risiko pasar; risiko kredit; risiko operasional; risiko likuiditas; risiko hukum; risiko reputasi; risiko strategik; risiko kepatuhan. ${ }^{39}$ Faktor-faktor penting yang harus diperhatikan pada lembaga keuangan di masa yang akan mendatang meliputi: perkembangan yang cepet; konsolidasi dan penggabungan lembaga keuangan; deregulasi akan mengizinkan persaingan dan tempat-tempat pasar swasta; adopsi yang tepat terhadap teknik informasi baru dan teknologi; peningkatan persaingan lembaga-lembaga keuangan; pertumbuhan yang cepat; peningkatan risiko kegagalan lembaga keuangan.40

Adakalanya bisnis dari perusahaan yang besar dan meluas sehingga dipecah-pecah menurut penggolongan bisnis. Akan tetapi, perusahaan yang dipecah-pecah tersebut menjadi perseroan terbatas yang mandiri dan dalam kepemilikan yang sama dengan kontrol yang masih tersentralisasi dengan batas tertentu. Pecahan perusahaan tersebut dan perusahaan lainnya yang mungkin lebih dulu ada, dimiliki dan dikomando oleh perusahaan yang mandiri. Perusahaan pemilik (pengomando) ini disebut juga perusahaan holding. ${ }^{41}$ Holding company dapat dilakukan dengan proses yaitu, proses residu, proses penuh, dan proses terprogram. ${ }^{42}$

Tipe pembentukan holding bank dan lembaga keuangan BUMN lainnya dengan proses penuh tipe $\mathrm{B}$, dimana perusahaan holding diambil dari perusahaan yang sudah ada, tetapi masih dalam kepemilikan yang sama dan saling berhubungan. PT Danareksa ditunjuk oleh pemerintah sebagai holding company. PT Danareksa merupakan BUMN yang bergerak dalam bidang investasi. PT hlm. 83 .

37 Mangasa Augustinus Sipahutar, Persoalan-Persoalan Perbankann Indonesia, Gorga Media, Jakarta, 2007,

${ }^{38}$ Krisna Wijata, Analisis Kebijakan Perbankan Nasional, Gramedia Pustaka Utama, Jakarta, 2010, hlm. 4.

${ }_{39}$ Bustari Muchtar. et. al., Bank dan Lembaga Keuangan Lain, Kencana, Jakarta, 2016, hlm. 87-89.

${ }^{40}$ Ibid., hlm. 30-31.

${ }^{41}$ Munir Fuady, Op. Cit., hlm. 85.

${ }^{42}$ Ibid., hlm. 6. 
Danareksa menjadi induk perusahaan (holding company), serta bank BUMN (Mandiri, BRI, BNI, BTN) dan lembaga keuangan non bank BUMN (PNM dan Pegadaian) telah eksis sebelumnya menjadi anak usaha.

Proses pembentukan holding company BUMN Perbankan di Indonesia dapat dilakukan dengan cara akuisisi (pengambil-alihan) saham pemerintah pada perusahaan-perusahaan tersebut oleh PT Danareksa. PT Danareksa (Persero) akan ditunjuk menjadi induk, sementara anggota holding akan terdiri dari beberapa bank dan perusahaan jasa keuangan lainnya. Anggota holding perbankan antara lain, BRI, Bank Mandiri, BNI, BTN, Bahana Sekuritas, PT Pegadaian, dan PT PNM, serta beberapa perusahaan keuangan milik pemerintah. Menurut Maryono Direktur Utama Bank BTN dengan terbentuknya holding perbankan, jaringan layanan perseroan akan semakin luas. ${ }^{43}$

Keuntungan holding company adalah: 1) kemandirian risiko; 2) hak pengawasan yang lebih besar; 3) pengontrolan yang lebih mudah dan efektif; 4) operasional yang lebih efektif; 5) kemudahan sumber modal; 6) keakuratan keputusan yang diambil. ${ }^{44}$ Sedangkan kerugian holding company adalah: 1) pajak ganda; 2) lebih birokratis; 3) management one-man show, 4) conglomerate game; 5) penutupan usaha; 6) resiko usaha. ${ }^{45}$

Beberapa kasus yang mungkin terjadi yang dapat merugikan pihak tertentu sebagai akibat perusahaan holding ikut campur dalam bisnis anak perusahaannya sebagai berikut: 1) kepailitan dan likuidasi; 2) under capitalization; 3) peran serikat pekerja; 4) merger, akuisisi, dan konsolidasi; 5) anak perusahaan sebagai guarantor; 6) aset anak perusahaan menjadi jaminan utang; 7) pemberhentian pengurus dan komisaris; 8) freezeout dan squeezeout; 9) transfer pricing. ${ }^{46}$

Visi membangun BUMN yang berdaya saing dan berkelas global, dengan keyakinan bahwa dalam era kompetisi global, kejayaan sebuah negara justru ditentukan oleh keunggulan perusahaan-perusahaannya dalam bersaing dengan

43“'Ini Manfaat Holding BUMN Perbankan di RI”, https://m.liputan6.com/bisnis/read/3481325/inimanfaat-ada-holding-bumn-perbankan-di-ri, diakses tanggal 6 Februari 2019.

44 Munir Fuady, Op. Cit., hlm. 93-94.

${ }^{45}$ Ibid., hlm. 94-95.

${ }^{46}$ Ibid., hlm. 105. 
perusahaan-perusahaan lain dalam konteks global. ${ }^{47}$ Salah satu langkah yang diambil pemerintah Indonesia untuk mewujudkan hal tersebut adalah melalui pembentukan holding company BUMN Perbankan. Kondisi aset perbankan nasional masih dipengaruhi oleh resiko kredit, apabila tidak dikelola secara efektif akan menanggung keberlangsungan bank tersebut. ${ }^{48}$

Asumsi dasar keberadaan BUMN merupakan kepanjangan negara dalam perekonomian nasional. ${ }^{49}$ Dengan kata lain, negara tidak absen, melainkan mengambil peran aktif melalui BUMN sebagai aktor ekonomi. Peranan BUMN tidak hanya sebatas mengelola sumber daya alam dan memproduksi barang yang menyangkut hajat hidup orang banyak tetapi juga dalam berbagai kegiatan produksi dam pelayanan seperti yang dilakukan perusahaan swasta. ${ }^{50}$ Kekuatan ekonomi negara yang lebih besar untuk melakukan kegiatan ekonomi dalam skala besar bagi penyediaan barang dan jasa bagi masyarakat. ${ }^{51}$ Dengan pertimbangan skala usaha dan efisiensi, negara melakukan kegiatan ekonomi secara langsung sehingga masyarakat lebih cepat dan murah untuk menikmati barang dan jasa.

Berdasarkan konteks perekenomian Indonesia, BUMN memiliki arti penting, bukan hanya eksistensinya tersirat dalam UUD 1945, melainkan karena diperlukan investasi untuk produk barang dan jasa yang tidak menarik atau terlalu besar untuk dapat dilakukan oleh swasta. ${ }^{52}$ Sektor perbankan khususnya, para pelaku ekonomi dapat masuk sesuai regulasi baik dari swasta maupun BUMN. Sektor perbankan merupakan bagian dari sektor jasa keuangan memiliki peranan penting dalam kegiatan ekonomi. Peran perbankan cukup besar dalam pembangunan bagi perekonomian. Sebagaimana dasar pembangunan ekonomi

47 Riant Nugroho Dwijowijoto, Randy R. Wrihatnolo, Manajemen Privatisasi BUMN, Elex Media Komputindo, Jakarta, 2008, hlm. 18. 5.

48 Iswi Hariyani, Restrukturisasi dan Penghapusan Kredit Macet, Elex Media Komputindo, Jakarta, 2013, hlm.

49 Fachry Ali, Antara Pasar dan Politik: BUMN di Bawah Dablan Iskan, Kepustakaan Populer Gramedia, Jakarta, 2013, hlm. 3.

${ }^{50}$ Pandji Anoraga, Op. Cit., hlm. 10.

${ }^{51}$ Ibid., hlm. 11.

${ }^{52}$ Ibid., hlm. 16. 
nasional adalah Pasal 33 UUD 1945. Efisiensi BUMN pada hakikatnya didasarkan pada keinginan lebih baik dan lebih efisiensi dalam melakukan kegiatan usaha. ${ }^{53}$

Secara umum kelebihan pembentukan holding company BUMN Perbankan antara lain: 1) Pengendalian dengan kepemilikan sebagian, melalui operasi holding company, sebuah perusahaan dapat membeli 5, 10, atau 50\% saham perusahaan lain. 2) Pemisahan risiko, karena berbagai perusahaan operasi dalam sistem holding company merupakan badan hukum terpisah, kewajiban dalam setiap unit terpisah dari unit lainnya.

Sementara itu, kelemahan pembentukan holding company BUMN Perbankan antara lain: 1) Pajak berganda parsial. Pengenaan pajak berganda parsial ini sedikit banyak mengurangi keunggulan holding company yang dapat mengendalikan anak perusahaan dengan kepemilikan terbatas, tetapi mengenai denda pajak tersebut jika lebih besar dari keunggulan holding company lainnya merupakan masalah yang harus ditentukan kasus per kasus. 2) Mudah dipaksa untuk melepas saham. Relatif mudah untuk menuntut dilepaskannya anak perusahaan dari holding company apabila kepemilikan saham ternyata melanggar undang-undang anti-trust.

Selain itu, holding-isasi BUMN memberikan manfaat yang dapat dilihat dari berbagai aspek dan sudut pandang perusahaan, negara, dan masyarakat. ${ }^{54}$ Pemimpin negara-negara menindaklanjuti visi ASEAN 2020 telah mendeklarasikan MEA. Sebagai bentuk komitmen tersebut, negara ASEAN setuju untuk mengimplementasikan MEA pada 2015 sebagai pasar tunggal dan berbasis produksi, serta menciptakan ASEAN sebagai kawasan ekonomi yang kompetitif, berdaya saing tinggi, dan terintegrasi penuh ke dalam ekonomi global. ${ }^{55}$ Lebih luas dari MEA adalah ASEAN Community dibentuk berdasarkan 3 pilar kerjasama, yaitu kerjasama ekonomi, politik, dan sosial politik. Dengan adanya berbagai kerjasama tersebut diharapkan terjadi aliran modal, barang, jasa, dan manusia ke dalam pasar tunggal yang berbasis produksi. Integrasi ini akan

${ }^{53}$ Ibid., hlm. 56.

54“Penguatan BUMN", http://pascasarjana.uai.ac.id/wp-content/uploads/2017/07/6.-PENGUATANBUMNedited1.pdf, diakses tanggal 6 Februari 2019.

55 R. Winantyo, et.al., Masyarakat Ekonomi ASEAN (MEA) 2015: Memperkuat Sinergi ASEAN di Tengah Kompetisi Global, Elex Media Komputindo, Jakarta, 2008, hlm. 37. 
mengakselerelasi perdagangan bebas, fasilitas bisnis, pengembangan perusahaan UMKM, serta mendorong investasi di wilayah ASEAN. ${ }^{56}$

Pembentukan holding company BUMN Perbankan merupakan salah satu langkah pemerintah Indonesia memperkuat industri keuangan dan perbankan nasional untuk menghadapi persaingan industri sejenis di kawasan. Apabila Indonesia tidak memiliki lembaga keuangan yang kuat, maka akan menjadi pasar perusahaan asing. Dengan adanya lembaga perbankan dan keuangan yang kuat yang dimiliki Indonesia akan mampu menjadi pelaku usaha yang menguasai pasar nasional dan mampu bersaing untuk masuk pasar di kawasan ASEAN melalui BUMN. Secara universal terdapat berbagai bentuk operasional untuk masuk di luar negeri dapat melalui: 1) bank koresponden; 2) kantor representative; 3) banking agency; 4) cabang/kantor cabang; 5) subsidiary; 6) bank joint venture; 7) bank konsorsium; 8) edge corporation; 9) international banking facilities. ${ }^{57}$

Berdasarkan uraiannya sebelumnya, lebih banyak kelebihan dibandingkan dengan kelemahan pada pembentukan holding company BUMN Perbankan di Indonesia. Upaya pemerintah tersebut diharapkan sebagai langkah alternatif mewujudkan lembaga keuangan yang kuat dan kompetitif secara global, khususnya di kawasan ASEAN. Sehingga bank asal Indonesia untuk masuk dalam pasar perbankan di negara-negara lain di ASEAN akan lebih mudah karena dengan dukungan permodalan yang kuat. Langkah tersebut merupakan bukan satu-satunya jalan untuk membentuk lembaga perbankan asal Indonesia yang kuat di kawasan ASEAN. Namun, apabila upaya tersebut dinilai kurang tepat, alternatif lain dapat diambil yaitu memperkuat BUMN Perbankan di dalam negeri dengan memperkuat internal perusahaan dan melakukan ekspansi ke pasar dalam negeri. Pasar perbankan dalam negeri merupakan pasar yang potensial karena luas wilayah dan jumlah penduduk yang banyak.

\footnotetext{
${ }^{56}$ Ibid., hlm. 38.

57 Munir Fuady, Hukum Perbankan Modern: Berdasarkan Undang-Undang Tabun 1998 Buku Kesatu, Citra Aditya Bakti, Bandung, 1999, hlm. 144.
} 


\section{Penutup}

Hasil penelitian ini menyimpulkan bahwa: Pertama, aspek-aspek yang harus diperhatikan dalam restrukturisasi BUMN Perbankan melalui pembentukan holding company di Indonesia antara lain aspek hukum, sumber daya manusia dan budaya perusahaan, perpajakan, dan dampak ekonomi. Dasar hukum holding company tersebut adalah: UU No. 19 Tahun 2003; UU No. 40 Tahun 2007; UU No. 10 Tahun 1998 jo UU No. 7 Tahun 1992; UU No. 5 Tahun 1999. Kedua, kelebihan pembentukan holding company BUMN Perbankan antara lain: kemandirian risiko; hak pengawasan yang lebih besar; pengontrolan yang lebih mudah dan efektif; operasional yang lebih efektif; kemudahan sumber modal; keakuratan keputusan yang diambil. Kelemahan pembentukan holding company BUMN Perbankan antara lain: pajak ganda; lebih birokratis; management one-man show, conglomerate game; penutupan usaha; resiko usaha.

Maka dari itu pemerintah hendaknya memperhatikan berbagai aspek yuridis maupun non yuridis, serta kelebihan dan kelemahan dalam pembentukan holding company. Pemerintah hendaknya segera membentuk holding company BUMN Perbankan setelah dilakukan studi kelayakan dan persetujuan otoritas yang berwenang. Upaya tersebut merupakan salah satu langkah alternatif yang dapat diambil pemerintah untuk mewujudkan lembaga keuangan dan perbankan yang kuat asal Indonesia di kawasan ASEAN.

\section{Daftar Pustaka}

\section{Buku}

Ali, Fachry, Antara Pasar dan Politik: BUMN di Bawah Dahlan Iskan, Kepustakaan Populer Gramedia, Jakarta, 2013.

Anoraga, Pandji, BUMN, Swasta, dan Koperasi: Tiga Pelaku Ekonomi, Pustaka Jaya, Jakarta, 1995.

Asyhadie, Zaeni, dan Budi Sutrisno, Hukum Perusahaan dan Kepailitan, Erlangga, Jakarta, 2012.

Bambang, Ahmad, Marketing Platform for BUMN: d'Gil Marketing 2, Gramedia Pustaka Utama, Jakarta, 2017.

Budianto, Agus, Merger Bank di Jakarta, Ghalia, Jakarta, 2004.

Djumhana, Muhammad, Hukum Perbankan di Jakarta, Citra Aditya Bakti, Bandung, 2012. 
Dwijowijoto, Riant Nugroho, dan Randy R. Wrihatnolo, Manajemen Privatisasi BUMN, Elex Media Komputindo, Jakarta, 2008.

Fuady, Munir, Hukum Perbankan Modern: Berdasarkan Undang-Undang Tahun 1998 Buku Kesatu, Citra Aditya Bakti, Bandung, 1999.

Hukum Perusahaan dalam Paradigma Hukum Bisnis: Berdasarkan Undangundang Nomor 40 Tahun 2007, Citra Aditya Bakti, Bandung, 2009.

Hariyani, Iswi, Restrukturisasi dan Penghapusan Kredit Macet, Elex Media Komputindo, Jakarta, 2013.

Hartono, Sri Redjeki, Kapita Selekta Hukum Perusahaan, Mandar Maju, Bandung, 2000.

Ibrahim, Johnny, Teori dan Metode Penelitian Hukum Normatif, Bayumedia Publishing, Malang, 2005.

Joyosumarto, Subarjono, B.A.N.K.I.R: Kepemimpinan Lembaga Perbankan Abad Ke21, Elex Media Komputindo, Jakarta, 2018.

Judisseno, Rimsky K., Sistem Moneter dan Perbankan di Jakarta, Gramedia Pustaka Utama, Jakarta, 2005.

Khairandy, Ridwan, Perseroan Terbatas: Doktrin, Paraturan Perundang-undangan, dan Yurisprudensi, Kreasi Total Media, Jakarta, 2009.

Moeljono, Djokosantoso, Reinvensi BUMN: Empat Strategi Membangun BUMN Kelas Dunia, Elex Media Komputindo, Jakarta, 2004.

Muchtar, Bustari, et. al., Bank dan Lembaga Keuangan Lain, Kencana, Jakarta, 2016.

Retnadi, Djoko, Memilih Bank yang Sehat: Kenali Kinerja dan Pelayanannya, Elex Media Komputindo, Jakarta, 2006.

Sipahutar, Mangasa Augustinus, Persoalan-Persoalan Perbankann Jakarta, Gorga Media, Jakarta, 2007.

Sobana, Dadang Husen, Hukum Perbankan di Jakarta, Pustaka Setia, Bandung, 2016.

Sugiharto, et.al., BUMN Jakarta: Isu, Kebijakan, dan Strategi, Elex Media Komputindo, Jakarta, 2005.

Supramono, Gatot, BUMN Ditinjau dari Segi Hukum Perdata, Rineka Cipta, Jakarta, 2016.

Syamsudin, M., Operasional Penelitian Hukum, RajaGrafindo Persada, Jakarta, 2007.

Usanti, Trisadini P., dan Abdul Somad, Hukum Perbankan Edisi Pertama, Kencana, Depok, 2017.

Wignjosoebroto, Soetandyo, Hukum: Konsep dan Metode, Setara Press, Malang, 2013.

Wijata, Krisna, Analisis Kebijakan Perbankan Nasional, Gramedia Pustaka Utama, Jakarta, 2010. 
Winantyo, R., et.al., Masyarakat Ekonomi ASEAN (MEA) 2015: Memperkuat Sinergi ASEAN di Tengah Kompetisi Global, Elex Media Komputindo, Jakarta, 2008.

\section{Peraturan Perundang-Undangan}

Undang-Undang Nomor 10 Tahun 1998 tentang Perubahan Undang-Undang Nomor 7 Tahun 1992 tentang Perbankan

Undang-Undang Nomor 5 Tahun 1999 tentang Larangan Praktek Monopoli dan Persaingan Usaha Tidak Sehat

Undang-Undang Nomor 19 Tahun 2003 tentang Badan Usaha Milik Negara

Undang-Undang Nomor 40 Tahun 2007 tentang Perseroan Terbatas

\section{Internet}

"Holding Jasa Keuangan Bank BUMN Molor Tiga Tahun dari Target", http:/ /amp.kontan.co.id/news/holding-jasa-keuangan-bank-bumnmolor-tiga-tahun-dari-target, diakses tanggal 6 Februari 2019.

"Ini Manfaat Ada Holding BUMN Perbankan di RI", https://m.liputan6.com/bisnis / read/3481325/ini-manfaat-ada-holdingbumnperbankan-diri, diaksestanggal6 Februari 2019.

"KPPU Holding BUMN Diberikan Konsesi Memonopoli", https://www.hukumonline. com/berita/baca/lt57e536c431443/kppu-holding-bumn-diberikan-konsesi-memonopoli, diakses tanggal 6 Februari 2019.

"List of Largest Banks in Southeast Asia", https://en.wikipedia.org/ wiki/List_of__largest_banks_in_Southeast_Asia, diakses tanggal6 Februari 2019.

"Penguatan BUMN", http://pascasarjana.uai.ac.id/wp-content/uploads/2017/ 07/6.-PENGUATANBUMN-edited1.pdf, diakses tanggal 6 Februari 2019.

"Perbanas Jumlah Bank Harus Dikurangi", https://finance.detik.com/moneter/ d-4404232/perbanas-jumlah-bank-harus-dikurangi, diakses tanggal6 Februari 2019.

"Restrukturisasi Holding Company", http://www.lmfeui.com/data/ Restrukturisasi_Holding_Company\%20Revisi\%202.pdf, diakses tanggal 6 Februari 2019. 